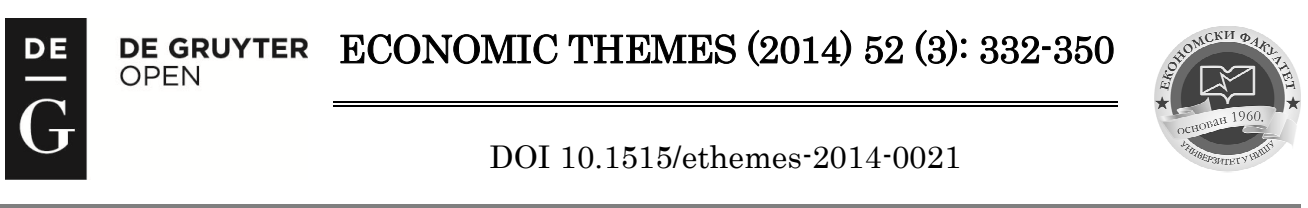

\title{
ANALYSIS OF NON-PERFORMING LOANS MOVEMENT AND PROFITABILITY OF THE BANKING MARKET IN BH
}

\author{
Almir Alihodžić \\ University of Zenica, Faculty of Economics, Zenica, BH \\ $\bowtie$ almir.dr2@gmail.com,almir_alihodzi@yahoo.com
}

UDC

$330.13: 347.734$

(497.6)

Original

scientific

paper

Received:

03.12 .2013

Accepted:

10.10.2014

\begin{abstract}
The main motive of business operations of any bank is to achieve the highest profit possible and utilise it to increase dividends to shareholders, as well as to create conditions to increase their financial and credit potential by reinvesting in shares. The most important quality indicator of a loan portfolio is the share of non-performing loans to total operating assets and liabilities. In the first quarter of 2013, a trend of increasing nonperforming loans in the legal entities sector increased by $2.6 \%$, while there was stagnation with the population, i.e. slight decrease. The main objective of this paper is to examine the impact of the global financial crisis on the movement tendency of non-performing loans in the banking market in $\mathrm{B} \& \mathrm{H}$, and their interdependence with the movement of profitability indicators by a simple regression equation.
\end{abstract}

Keywords: non-performing assets, return on average equity, return on average assets, regression analysis.

\section{Introduction}

Profitability in the form of retained earnings is one of the key sources of capital formation. A healthy banking system is built on profitable and adequately capitalized banks. Profitability is an indicator that reveals the competitive position of a bank in the banking market and the quality of its leadership. Thus, the profitability enables the bank to maintain a certain risk profile and provide assurance in respect of short-term problems. An income statement is a key source of information about the profitability of a bank, it reveals sources of income of a bank, as well as the quality of the loan portfolio and focus on total expenditures. In addition, the structure of the bank's income statement should indicate the business orientation of the bank. Structural changes in capital requirements and monetary policy measures can sometimes 
have an impact on changes in the structure and stability of the bank's profits. The restrictive nature of the statutory minimum capital may affect the banks to change their business mix in favour of activities and assets that include lower levels of capital. However, even though such property carries less risk, it can ultimately affect the lower yields. Excess of required reserves and liquidity reserves damages and profits can encourage mediation. Taxation is another important factor that affects the profitability of a bank because it affects the competitiveness of various instruments in various segments of the financial markets (Greuning, Bratanovic 2009, 101).

Each bank manager has four main tasks. The first task is to secure a sufficient amount of cash so the bank is able to pay all deposits in the event of withdrawal, or when the bank loses deposits by the request for payment. Therefore, in order to provide enough cash, the bank must deal with the management of liquidity, i.e. obtaining a sufficient amount of liquid assets to be able to meet its obligations to holders of deposits. As the second task, the bank manager must follow the strategy of small exposures to obtain the properties of low default risk and diversify the assets owned by the bank. The third task of the manager is reflected in the acquisition of assets with minimum cost. As a final step, the manager must take into account the amount of capital that the bank would have to maintain and obtain needed capital. The banks have to make decisions about the amount of capital that must be held practically for at least three reasons. First, bank capital serves as a security compound in the prevention of the bank failure, or a situation in which the bank can not meet its obligations to depositors and other creditors and therefore goes bankrupt. The second reason lies in the fact that bank capital affects the earnings of the owner, i.e. shareholders of the bank. Finally, the minimum amount of bank capital (prescribed minimum bank capital) is determined by the regulatory body (Mishkin, 2010, 231).

The paper is structured in three parts. The first part describes the theoretical basis for managing liquidity and profitability of the bank. The second section elaborates on the current state of the banking market in $\mathrm{BH}$ regarding the tendency of basic indicators of financial health. The last section analyses the possibility of applying applicative simple regression model with respect to determining the strength and direction of the relationship between the variables of profitability and non-performing bank loans. Finally, the conclusions are given as results of the study..

\section{Liquidity and Capital Adequacy Management}

The liquidity of the bank is its ability as a debtor to pay a monetary obligation when due. Both external and internal factors affect the bank's ability to settle its obligations. The most important factors influencing the ability of 
banks are primarily factors of investment and allocation of resources, as well as the conservative model of investment and allocation of resources. The method of investments and allocation of resources is based on the fact that long-term investments and investments are realized only in the long-term sources of funds and short-term investments and investments partly from long-term sources and the remainder of the short-term sources of funds. In contrast to the methods of investments and allocation of resources, a conservative method of investment and allocation of resources is based on the assumption that the total investments and loans are covered by long-term sources, while cash and negotiable securities are covered by short-term sources of funds. A bank's liquidity depends on the degree of synchronization of cash flow income and expenditure of funds. So, if the pace of cash flow is in line with the dynamics of the outflow of resources for the settlement of the overdue financial obligations to the bank, then the problem of maintaining liquidity is much easier to overcome by the banks. A long-term goal of every bank is to establish the optimal ratio of cash balances in order to satisfy the principle of optimal liquidity and profitability. In modern banking practice, the most important models for optimizing cash balances are (1) Baumol's Model, (2) Miller - Orr Model, (3) Beran Model and (4) White and Normal model. The first indication of the bank's liquidity is reflected in the ability to perform its obligations to the citizens in due time. The bank can also maintain its liquidity through credit functions, provided that it synchronizes the terms of loan repayment deadlines with deadlines for returning deposits and ensures higher interest rates on loans given than interests on deposited funds (Vunjak, Kovacevic 2011, 354-355).

Upon the agreement between banking representatives of developed countries the Basel Committee on Banking Supervision ${ }^{1}$ was founded. The Basel Agreement requires the bank capital to be at least $8 \%$ of their riskweighted assets. It was adopted by 100 countries, including the United States. Assets and off-balance sheet activities are divided into four categories, each with different weighting that reflects a certain level of credit risk. The first category carries a weight equal to zero and includes items for which there is little risk of default, such as reserves or state securities of (developed) member countries of the Organization for Economic Cooperation and Development OECD. The second category has a weighting of $20 \%$ and includes bank claims from member countries of the OECD. The third category has a weighting of $50 \%$ and includes municipal bonds and mortgages on real estate. The fourth category has the highest weight of $100 \%$ and includes other loans to individual customers and businesses. The 1996 Amendment on Market Risk specifies the minimum required level of capital in accordance with the risks to which banks

\footnotetext{
${ }^{1}$ Named so because it meets under the auspices of the Bank for International Settlements in Basel, Switzerland, which introduced the so-called Basel Agreement on a prescribed level of regulatory capital.
} 
are exposed based on trade. In time, limitations of the Basel Agreement showed, as potential risk for the banks, indicated by different weights, can greatly differ from the actual risks faced by a bank. The outcome is known as regulatory arbitrage. In their books, banks keep property for which the same level of regulatory capital is determined, but it is relatively risky, e.g. loan companies with poor credit ratings, while out of business books they keep low-risk assets, such as loan companies with high credit ratings. Therefore, the Basel Agreement can lead to increased exposure to risk, which is the opposite of its original intent. In order to eliminate the aforementioned limitations, the Basel Committee on Banking Supervision issued a proposal for a new agreement, often referred to as Basel II and primarily referring to international banking. The European Commission adapted the provisions of Basel II to domestic credit institutions and investment companies in the form of the Capital Adequacy Directive - CAD3, and other European countries (including Serbia and Bosnia and Herzegovina) are trying to do it through their laws and decisions. The European Union began the implementation of CAD3 in 2007 and 2008.

In the whole world, the adaptation to the provisions of the Basel II is in progress or preparation. ${ }^{2}$ Certainly, the adoption of Basel II is one of the most important events of the decade in the global banking industry. The most important contributions Basel II should provide are: decrease in the required level of capital (but by decreasing the capital of less risky banks and increase the capital of risky banks), improved risk management, higher financial stability and improved financing terms for high quality clients and worse for low quality clients. The main feature of Basel II is its structure, which is based on three main pillars:

I minimum requirement for capital,

II capital adequacy control process and

III market discipline.

$\frac{\text { Basic }+ \text { Additional Capital }}{\text { Credit }+ \text { Market }+ \text { Operational risk }}=$ Quota of Equity Capital (Minimum of 8\%)

A Minimum requirement for capital is defined by calculating the capital adequacy, which is a ratio of equity capital and the amount of risk to which the bank is exposed, or weighted assets. The upper part of the fraction remained the same as in Basel I, while in the lower part of the fraction the introduction of operational risk in the calculation is new, as well as that the following models are available to the banks for the calculation of credit risk:

\footnotetext{
${ }^{2}$ The U.S. decided to postpone the introduction of the new Capital Accord and then to initiate the implementation of Basel II with certain modifications in 2007.
} 
1) Standard approach.

2) Internal ratings based approach - IRB:

- Foundations internal ratings based approach - FIRB and

- Advanced internal ratings based approach-AIRB.

Chart 1: The structure of the Basel Capital Accord

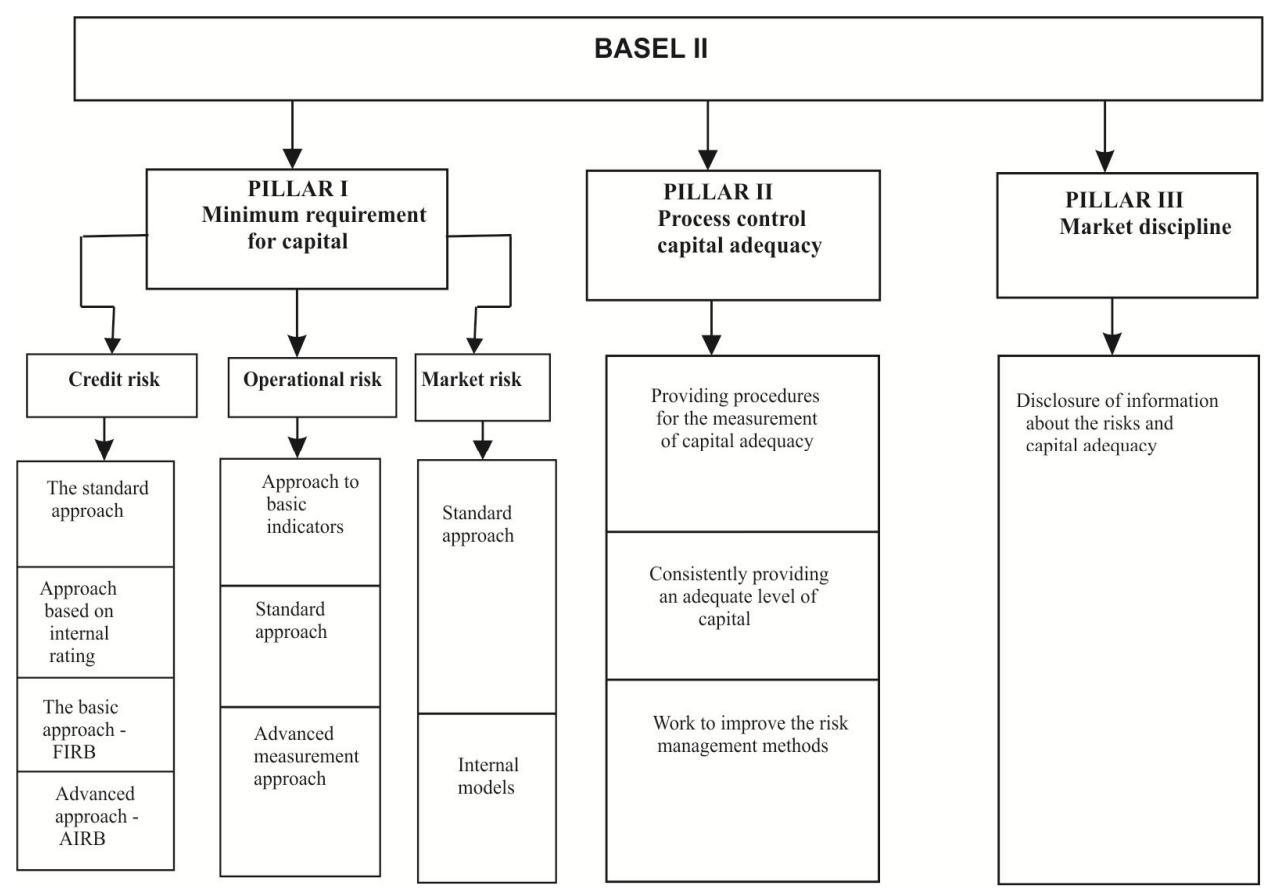

Source: Milakovic, N. (2004): Basel II despite the current delay - the project of an international agreement on bank equity ", Paragraf Press, No: 197.

The regulatory framework of Basel II is designed with the aim to prevent the consequences of the crisis. The global financial crisis has underscored flaws in its design, since it did not help in its prevention. Two years after the collapse of Lehman Brothers - the Basel Committee on Banking Supervision issued new guidelines on Basel III - the regulatory framework to improve the ability of the banking sector to absorb shocks arising from financial and banking pressures in general management in banks and to increase the transparency of banks.

In order to complete the principles and further strengthen the framework for liquidity risk management in the bank, the Committee has developed two minimum standards for funding liquidity, namely: the liquidity coverage ratio LCR and net stable funding ratio - NSFR. The liquidity coverage ratio (LCR) 
should provide the bank's resilience to disruptions in liquidity for a period longer than 30 days, in terms of high-quality liquid assets that are held in reserve to compensate for the net cash outflow. This ratio is determined based on the results of a short-term stress scenario that is created based on the conditions defined in the document of the Basel III rules. The net stable funding ratio (NSFR ) requires a minimum amount of stable funding sources at the bank in relation to the liquidity profile of assets and the potential for contingent liquidity arising from off-balance sheet obligations for a period longer than one year. This ratio is designed to provide a sustainable maturity structure of assets and liabilities in the balance Bank (Matic, 2011).

Total regulatory capital according to Basel III should consist of the sum of the following elements: (1) Tier 1 capital - Tier 1 (Going Concern Capital), which consists of : Common stock capital - Tier 1 and additional capital - Tier 1, (2) Tier 2 capital - Tier 2 capital (Gone concern capital). A significant change in the concept of Tier 1 capital is the change in the structure, as the Basel III instead of the concept of core capital - Tier 1 (Basel II), clearly distinguishes the category of the equity capital of the Joint additional capital within Level 1 as well as the importance of structure for the coverage of business losses. Member countries of the Basel Committee begin the implementation of the new standards of 1 January 2013, with an addition to embed amended standards into national legislation first. Capital adequacy of their banks must meet the following minimum levels: (1) $3.5 \%$ - common equity level risk/ weighted assets, (2) $4.5 \%$ - Tier 1 capital / risk -weighted assets, i.e. $8 \%$ of the total capital / risk weighted assets. The prescribed minimum for Tier 1 and Tier 2 capital will be met in phases from 1 January 2013 to 1 January 2015 (Matić, 2011b). Therefore, Basel III highlights the changes, i.e. new rules in the following key areas: the quality of capital, leverage ratio and liquidity requirements. Basel III is the strengthening of global capital standards in certain cases.

\section{Profitability and Non-Performing Assets}

The objective function of banks in a market economy is the establishment of an adequate rate of return per unit of equity capital. An alternative formulation of the objective function of banks is related to the fact that it seeks to maximize the market value of the company. If the anticipated flows of net yield, or the bank profits in future periods, is discounted, the current market value of the bank is obtained. Therefore, if a bank does not achieve a sufficient amount of profits using a discount rate, a low current market value is obtained, which ultimately leads to a decrease of share prices of observed banks in the secondary market, which negatively affects the investment of capital in such a bank. And vice versa, an increase in the market price of bank shares in the capital market has a positive impact on the demand for such shares in the secondary market and the absorption of new quantum of shares in the primary market. The 
achievement of satisfactory rate of profit per unit of equity capital is the basis for further expansion of banks in a market economy. A profitable bank increases its share capital by keeping a part of the realized profit, or through the issuance of additional shares in the primary market. An increase in share capital is necessary in for the bank's growth and because of institutionally prescribed minimum ratio between the amount of bank capital and the amount of assets in the bank's balance sheet (Cirovic 2001, 63). In order for the owners of the bank to know whether the bank is managed well, they need good indicators of profitability. The basic measure of the bank profitability is the return on assets ROA, i.e. net profit after tax for every (RSD) property:

$$
R O A=\frac{\text { Net profit after tax }}{\text { Assets }}
$$

ROA provides information on how to manage the bank effectively, because it shows how much profit is generated by all (RSD) assets in average. Bank shareholders (owners) are most interested in what is the bank profit on their invested capital. This information can be obtained through another bank profitability indicator called return on equity - ROE, i.e. net profit after tax for each (RSD) of equity banks (Mishkin 2010, 232):

ROE $=\frac{\text { Net profit after tax }}{\text { Equity Capital }}$

Between the return on assets and return on invested capital, there is a direct relationship expressed through the equity multiplier, or earnings multiplier EM, which represents the amount of assets at a (RSD) of equity:

$E M=\frac{\text { Assets }}{\text { Equity Capital }}$

Under conditions of presence of high-risk banking, traditional methods of determining the profitability of banks are extended through the method of Risk Adjusted Return on Capital - RAROC, as well as the method of Shareholders Value Added - SVA. The RAROC method is a return of capital adjusted for risk, while SVA method is the added value of equity. Both methods are based on the use of CAR model as a measure of an economic level of bank capital that is at risk. Thus, the CAR model is the last refuge of a possible insolvency of the bank. THE RAROC and SVA methods principally apply to almost all major commercial banks in the U.S. and Europe. The RAROC method is calculated using the following formula:

$R A R O C=\frac{\text { Interest Margin }- \text { Expected Losses }}{\text { CAR }(\text { Economic Capital of Bank })}$ 
The interest margin is an expected return on placed loans. If expected loss is subtracted from an interest margin, a net interest margin is obtained. In practice, the RAROC rate for specific loans is usually compared with the marginal rate of return. ${ }^{3}$ By the application of the RAROC method, the bank decides whether to approve or not to approve a credit ranking. The bank mainly approves loan placement if an interest margin increased by a commission is equal to or higher than the rate of RAROC. The SVA method, showing a net profit of a bank after deducting all bank costs and deduction of a limit the rate of return of capital, is calculated as follows (Vunjak, Kovacevic, 2011, 390-391):

SVA $=$ Interest Margin - Expected Losses - CAR (25\%)

The SVA method shows a net increase in bank capital above the increase in economic capital (CAR), whose function is to cover unexpected bank losses. In order for a commercial bank to approve credit standings, it is required for the SVA indicator to have positive value presented in absolute terms. In order to track performance and quality decision making effectively, the management of the bank should be comparing its profitability indicators with specific indicators of the control group of banks, as well as the indicators achieved by the bank in previous periods of 3 to 5 years. A comparison of current profitability indicators with indicators from the previous period is performed to determine the development trend of a bank, i.e. determine developments of a bank in a given period.

The risk rate of bank assets, by its individual elements and elements of offbalance sheet records, is prescribed by the Central Bank. The first requirement of a harmonized scope of the bank's business refers to a harmonized relationship between bank capital and the amount of risk-weighted assets. Total Assets represent the balance of all of the assets of the prescribed form of the balance sheet (BS) and is presented on a net basis, which means they are reduced by the reserves for potential losses. ${ }^{4}$ In contrast to total assets, average assets are an average balance of assets during the observed period. Average assets in the first quarter represent average monthly asset items for the first three months, in the second quarter for the first six months, in the third quarter for the first nine months and in the fourth quarter for the average monthly balances of assets for the year. Risk-weighted assets are the sum of multiplied appropriate rate (weight) and the risk of assets, or credit off - balance equivalents items at risk.

Non-performing assets are the items of assets when the principal and/or interest are due and not paid for more than 90 days after their initial contractual maturity or when they are classified in categories C, D and E, or when the

\footnotetext{
${ }^{3}$ Represents the lowest rate of return to shareholders' equity required by the shareholders.

${ }^{4}$ Reserves for losses consist of general and specific provisions for credit losses, leasing and losses due receivables and the general and the special provisions for other items of the balance sheet assets.
} 
obligations of users by interest for which a borrower is late with payment for more than 90 days after their initial contracted term. The bank's assets exposed to credit risk consist of the following items: 1) bank's balance sheet: loans, advances, investments, debt securities, receivables from interbank balances and all other items for which the bank is exposed to the risk of settlement failure 2 ) in bank off-balance bank: issued guarantees, letters of credit, irrevocably approved and unutilised credits, and any other items that are potential liabilities of the bank (Alihodzic, 2012).

For general credit risk (GCR) and impairment losses (PLL), the bank formed a reserve for loan losses (LLR), which, when conditions are met are used for writing off poorly classified assets, in part or as a whole. Loan loss reserves established for items of assets classified as category "A" consist of general reserves for loan losses (GRLL), and loan loss reserves established for items of assets classified as category B, C, D and E are separate reserves for credit losses (SPCL). Banks classify assets into five categories, as well as reserves for each category, as illustrated by the following table.

Table 1: Classification of Balance Sheet Positions of Assets

\begin{tabular}{||l|c|c||}
\hline \multicolumn{1}{|c|}{ Category of Assets } & Type of Assets & \% of Reserves \\
\hline Category "A" & Good Assets & $2 \%$ of GRLL for GKR \\
\hline Category "B" & Assets for Special Purpose & $5 \%-15 \%$ of SPCL for SCL \\
\hline Category "C" & Post-Standard Assets & $16 \%-40 \%$ of PRCL for PCL \\
\hline Category "D" & Doubtful Assets & $40 \%-60 \%$ PRCL for PCL \\
\hline Category "E" & Loss & $100 \%$ PRCL for PCL \\
\hline
\end{tabular}

Source:http://www.cbbh.ba/files/obrasci/sfsi/fsi_instruction_bs.pdf (Access: 4.8.2013.)

In accordance with the Decision on the Amendment to the Decision on Minimum Standards for Credit Risk Management, as of 31 December 2010, the banks in the Republic of Srpska have been obliged to calculate regularly the LLR for estimated losses that can be incurred based on classified assets. Nonperforming loans are the loans classified into categories C, D and E, i.e. the loans with past due principal and/or interest not charged for more than 90 days from their contractual maturity or loans for which the interest is payable and which is charged at the time capitalized. In accordance with the Decision on the Amendment to the Decision on Minimum Standards for Credit Risk Management, as of 31 December 2010, the banks in the Republic of Srpska have been obliged to present in the balance sheet loans classified in the category E until their final write-off or collection. 


\subsection{Tendency of Financial Health Indicator Movement in Banking Sector in $\mathrm{BH}$}

The situation in the banking sector has significantly changed since the previous period. Weak domestic demand in 2012, as well as low expected growth in future periods, caused a series of chain reactions that ultimately contributed to the increase in systemic risk. Changes in the banking sector in relation to the previous period were primarily due to trends in the macroeconomic environment, banks' reaction to changes in the environment in terms of changes in bank policies regarding the manner of financing and regulatory changes.

Specifically, based on a combination of effects of all these factors, a standard set of indicators of the banking system's health indicates a higher level of capitalization and lower systematic risk. Weak economic activity in the country since mid-2009 greatly reduced an income of households, whereby direct effects on the banking system are reflected in the decline in demand for long-term loans and deterioration in portfolio quality of banks (Central Bank 2012,52 ). The table below illustrates the tendency of movement of financial indicators of the banking system in $\mathrm{BH}$ (core capital to risk weighted assets, net of capital to risk weighted assets, non-performing assets to total assets, return on average assets and return on average shareholders' equity) for the period 2006 - Q1/2013.

Table 2: Financial Indicators of Banking Sector Stability in BH 2006 - Q1/2013.

\begin{tabular}{|l|l|l|l|l|l|}
\hline Years & $\begin{array}{l}\text { Core capital } \\
\text { to risk } \\
\text { weighted } \\
\text { assets }\end{array}$ & $\begin{array}{l}\text { Net capital to } \\
\text { risk weighted } \\
\text { assets }\end{array}$ & $\begin{array}{l}\text { Non- } \\
\text { performing } \\
\text { assets to } \\
\text { total assets }\end{array}$ & $\begin{array}{l}\text { Return on } \\
\text { average } \\
\text { assets } \\
\text { (ROAA) }\end{array}$ & $\begin{array}{l}\text { Return on } \\
\text { average } \\
\text { equity } \\
\text { capital } \\
\text { (ROAE) }\end{array}$ \\
\hline 2006 & 13,62 & 17,68 & 2,47 & 0,87 & 8,42 \\
\hline 2007 & 12,60 & 17,14 & 1,82 & 0,87 & 8,95 \\
\hline 2008 & 12,01 & 16,26 & 2,16 & 0,41 & 4,34 \\
\hline 2009 & 12,39 & 16,07 & 3,90 & 0,08 & 0,84 \\
\hline 2010 & n/a & 16,17 & 8,10 & $-0,60$ & $-5,49$ \\
\hline 2011 & 13,57 & 17,07 & 8,79 & 0,70 & 5,90 \\
\hline 2012 & n/a & 16,41 & 10,26 & 0,86 & 6,99 \\
\hline Q1/2013 & 14,58 & 17,24 & 10,60 & 0,26 & 2,01 \\
\hline
\end{tabular}

Source: http://www.cbbh.ba/index.php?id=618\&lang=hr (Access: 2.8.2013) 
From the table above it $\mathrm{i}$ clear that the lowest value of the return on average assets (ROAA) was registered $2010(-0.60 \%)$, which represents a relative reduction of about 0.7 percentage points compared to the previous year. Also, the return on average equity (ROAE) for the entire banking system was $(-5.5 \%)$ in 2010, representing a relative reduction of 6.3 percentage points compared to the end of the 2009. The banking sector in BH has been influenced by the economic crisis and recession, which is ultimately reflected in a profitability decline in 2010. Non-performing assets to total assets is in 2010 had a tendency of linear trends with indicators of profitability and a rapid increase in value compared to 2006 when it was $2.47 \%$. Therefore, the quality of bank assets in 2010 continued to deteriorate mainly due to the growth of bad debts, as well as changes to regulations in the Republic of Srpska, whereby on 31 December 2010 previously off-assets classified as "E" - the loss of the commercial banks in the Republic of Srpska ${ }^{5}$ were transferred to the balance sheet.

The share of non-performing assets to total assets increased from $3.90 \%$ at the end of 2009 to $8.10 \%$ in late 2010. Profitability ratios in 2011 indicate a noticeable improvement over the same period in 2010. Return on average of shareholders' equity $(-5.5 \%)$ in 2010 was increased to $5.9 \%$ in late 2011 , whereby the highest value of this ratio observed in foreign-owned banks was $(6.4 \%)$, while with the locally owned banks it was $(2.1 \%)$. Unlike the return on average equity, an indicator (ROAA) increased from $(-0.60 \%)$ at the end of previous year to $0.70 \%$ in late 2011. Value indicators (ROAA) for foreignowned banks stood at $0.70 \%$, while for banks with mainly domestic ownership it was $0.40 \%$.

This improvement in operating results compared to the previous year is primarily the result of an increased lending activity, and in part because of obsolete problems of the recession. In contrast to profitability, non-performing assets classified in risk categories $\mathrm{C}, \mathrm{D}$ and $\mathrm{E}$ increased by $10.9 \%$ compared to the end of 2010. Since the credit portfolio is the most important item of total assets, the most important part of non-performing assets includes nonperforming loans, whose share was $93.6 \%$ in non-performing assets at the end of 2011. In 2012, the ROAE indicator also increased from 5.90\% in 2011 to $6.99 \%$ at the end of 2012, with the highest value of this ratio observed in foreign-owned banks $(7.64 \%)$, while with the locally owned banks it was 2.53 $\%$. Unlike the ROAE indicators, a return on average assets increased from 0.70 $\%$ at the end of previous year, to $0.86 \%$ at the end of 2012. In the first quarter of 2013 , the increase in non-performing loans was in the two sectors with the highest share, in the manufacturing sector $(4 \%)$ or 10 million BAM, i.e. increase participation from $15.9 \%$ to $16.6 \%$, and in trade by $1 \%$, or 4 million BAM, which represents an increase of participation by 0.3 percentage points.

\footnotetext{
${ }^{5}$ Non-performing assets consist primarily of non-performing loans which have delays in repayment and adversely affect the loan portfolio of banks.
} 
The Chart below illustrates the range of profitability - ROAE and ROAA for the period 2008 - 2012.

Chart 1: Changes in Profitability of Banking Sector in BH 2008 - 2012

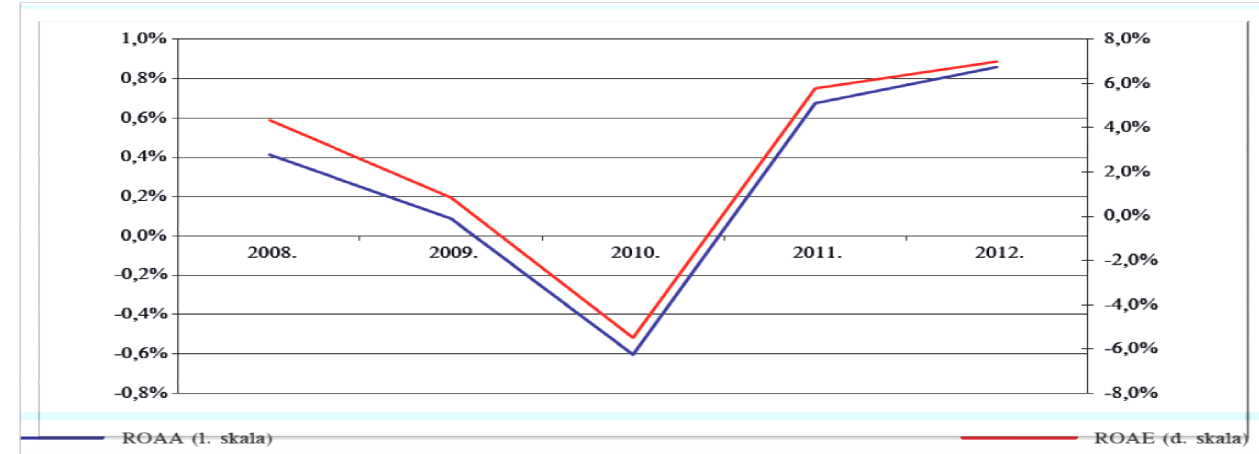

Source: http://www.cbbh.ba/files/godisnji_izvjestaji/2012/GI_2012_hr.pdf, Annual Report, 2012, p. 91 (Access: 4.8.2013)

\subsection{Data and Regression Analysis}

The quality of assets in the last quarter of 2012 began to deteriorate, whereby the result for the whole year recorded a relative increase in nonperforming assets by $1.4 \%$ compared to the previous year. Primarily, the deterioration in asset quality affected an increase in non-performing loans in the portfolio, which is illustrated in the Table below.

Table 3: Structure of Loan According to Quality of Assets

\begin{tabular}{|l|c|c|c|c|c|c|}
\hline \multicolumn{1}{|c|}{ Year } & A & B & C & D & E & $\begin{array}{c}\text { Non- } \\
\text { performing } \\
\text { loans (C - E) }\end{array}$ \\
\hline 2011 & $76,6 \%$ & $11,6 \%$ & $3,3 \%$ & $3,4 \%$ & $5,1 \%$ & $11,8 \%$ \\
\hline 2012 & $76,8 \%$ & $10,0 \%$ & $3,5 \%$ & $4,0 \%$ & $5,6 \%$ & $13,2 \%$ \\
\hline
\end{tabular}

Source:http://www.dep.gov.ba/dep_publikacije/ekonomski_trendovi/Archive.aspx?lan gTag=bs-BA\&template_id=140\&pageIndex=1, Annual Report, 2012, p. 30.

Loans granted in 2012 accounted for $66.7 \%$ of the total assets of the banking sector, which indicates that the $\mathrm{BH}$ banks almost exclusively engaged in traditional banking activities without going into too much other work of modern banking, such as securities trading and investment banking. The ratio of bank loans to GDP and the private sector in 2012 amounted to $51.8 \%$, while the ratio of total banking assets to GDP stood at $80.4 \%$ and the data from 2011 are almost similar (DEP 2012, 30). 
In the regression model, which will be the subject of the analysis, we will follow the interconnectivity and interdependence of movement of nonperforming loans to total assets and return on average assets of the banking sector in BH for the period 2006 - Q1/2013. Using a simple linear regression model the relationship between the two parameters was analysed. The equation of this model has the following form:

$$
Y_{i}=\alpha+\beta X_{i}+\varepsilon_{i}
$$

where: $Y$ - dependent variable, in our case the return on assets/return on average shareholders' equity, $X$-independent variable, i.e. non-performing assets /loans to total assets, $\alpha$ and $\beta$ are unknown parameters that need to be estimated, and $\varepsilon$ - is a stochastic variable that refers to the non-systematic influences on the dependent variable and it is called error relationship.

\subsection{Research Results}

The regression equation is based on empirical data, where based on the result of the equation, we can conclude that the changes in the movement of non-performing loans to total assets will have implications for the return on average assets in terms of their increase or decrease. The Chart below illustrates a linear regression between the direction of non-performing assets and return on average assets for the period 2006 - Q1/2013.

Chart 2: Simple Linear Regression Between Direction of Non-Performing Assets and Return on Average Assets of Banking Market in BH 2006 - Q1/2013

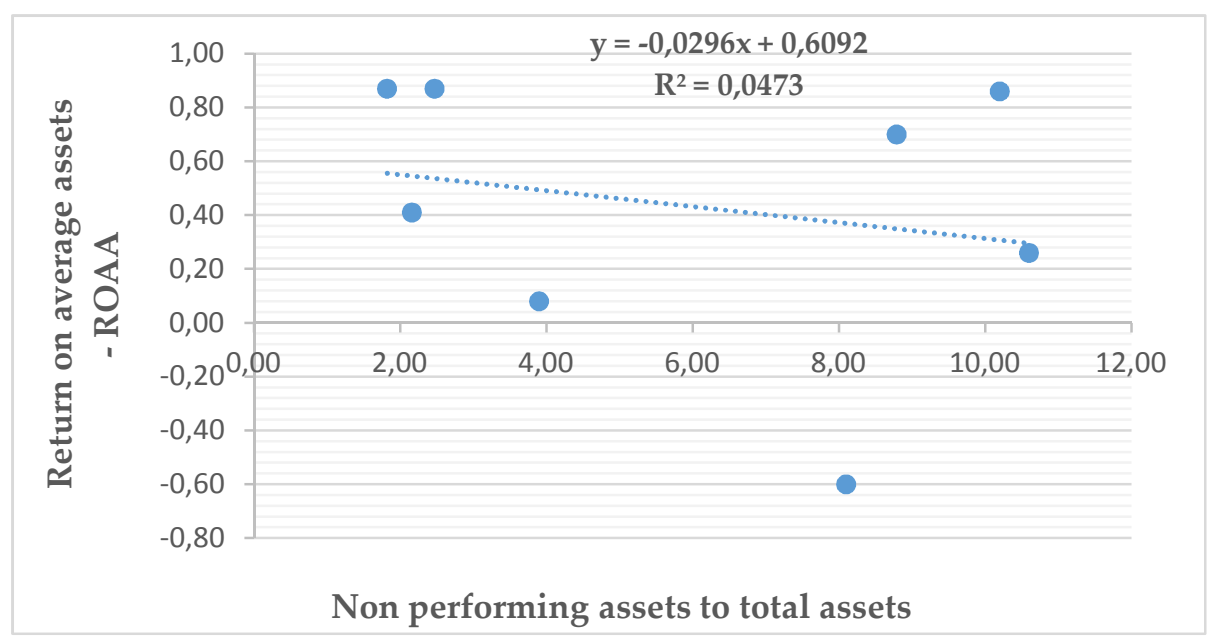

Source: Calculation by Author 
Based on the scatter diagram, i.e. coefficient of correlation $(r=-0.2175)$ it can be concluded that among these variables there is a statistical correlation of a negative direction, i.e. that the increase of the amount of non-performing loans will affect reducing the return on average assets (ROAA). The empirical relationship $\mathrm{F}=52.39$ (Table 4 ) clearly shows that the regression model is statistically significant. The coefficient of determination is $r^{2}=0.04372$ and the model is interpreted by $4.37 \%$ deviation. Based on these parameters and indicators of the regression analysis, it can be concluded that the model applied from a statistical point of view has quite good properties.

Table 4: Pearson Correlation Coefficient Between Non-Performing Assets and Return on Average Assets of Banking Market in BH 2006 - Q1/2013.

\begin{tabular}{lll}
\hline & Variable 1 & Variable 2 \\
\hline Mean & 6,510 & 0,368571 \\
Variance & 14,30023 & 0,272948 \\
Observation & 7 & 7 \\
Df & 6 & 6 \\
Pearson correlation & $-0,21755$ & \\
Covariance & $-0,37079375$ & \\
Correlation & $-0,2175486$ & \\
Determination & 0,04732740 & \\
T-Test & 4,015917 & \\
\hline
\end{tabular}

Simple Linear Regression - Ungrouped Data

\begin{tabular}{llll}
\hline & Value & S. E. & T - Stat \\
\hline Beta & 0,459148482 & 0,45437523 & 1,010505 \\
Elasticity & $-0,013913526$ & 0,061470885 & $-0,22634$ \\
\hline
\end{tabular}

Simple Linear Regression - Analysis of Variance

\begin{tabular}{llll}
\hline \multicolumn{1}{c}{ ANOVA } & \multicolumn{1}{c}{ DF } & Sum of Squares & Mean Square \\
\hline Regression & 1 & 0,016609967 & 0,01661 \\
Residual & 5 & 1,621075747 & 0,324215 \\
Total & 6 & 1,637685714 & \\
F - Test & 52,39186 & & \\
\hline
\end{tabular}

Source: Calculation by Author 
The regression equation is equal to:

$Y=-0.0296 X+0.6092$

$R^{2}=0.0473$

According to the previous equation, if the parameter of non-performing loans is increased by $1 \%$, the parameter of the return on assets will be reduced by an average of about 0.03 percentage points. An evaluation of the parameter is statistically accurate. Therefore, the analysis of the relationship between parameters of non-performing assets and return on average assets in the banking market in $\mathrm{BH}$, based on the applied model and the given data, shows that between these parameters there is a strong non-linear statistical correlation in the negative direction.

Presented below is the regression model where we analyse the interdependence of non-performing assets and return on average shareholders' equity in the banking market in $\mathrm{BH}$. The goal is to determine the extent to which non-performing loans affect the decline of return on average shareholders' equity in the banking market in $\mathrm{BH}$. Therefore, the relationship between the dependent variable return on average shareholders' equity $(\mathrm{Y})$ and the independent variables in non-performing assets (X) is analysed. The analysis applies a simple regression model presented by the scatter diagram below with marked regression direction.

Chart 3: Simple Linear Regression between Direction of Non-Performing Assets and Return on Average Shareholders' Equity in Banking Market in BH 2006. - Q1/2013

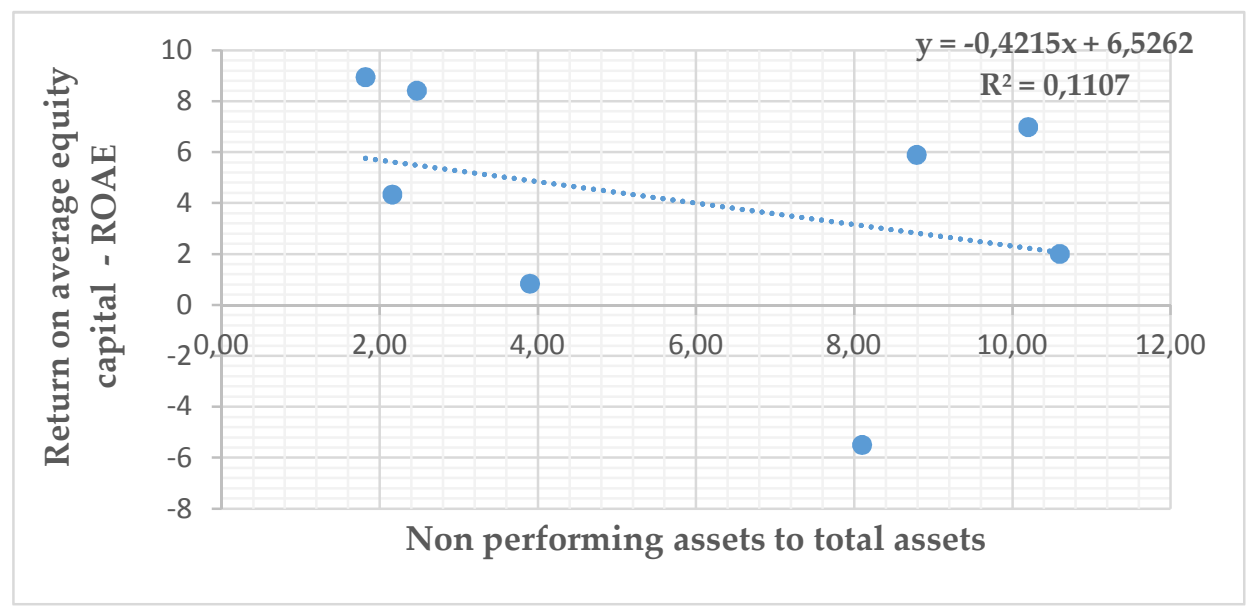

Source: Calculation by Author

The empirical relationship $F=1.61$ (Table 5) clearly shows that the regression model is statistically significant. The coefficient of determination is 
$r^{2}=0.11065$ and the model is interpreted with $11.06 \%$ deviation. Based on these parameters, as well as indicators of the regression analysis, it can be concluded that the model applied from the statistical point of view has quite good properties.

Table 5: Pearson's Correlation Coefficient between Non-Performing Assets and Return on Average Equity (ROAE) in Banking Market in BH 2006 - Q1/2013.

\begin{tabular}{lll}
\hline & Variable 1 & Variable 2 \\
\hline Mean & 3,362857 & 6,51 \\
Variance & 23,05539 & 14,30023 \\
Observation & 7 & 7 \\
Df & 6 & 6 \\
Pearson correlation & $-0,22314$ & \\
Covariance & $-5,273375$ & \\
Correlation & $-0,332642088$ & \\
& & \\
Determination & 0,110650759 & \\
T - Test & 1,234968 & \\
\hline
\end{tabular}

Simple Linear Regression - Ungrouped Data

\begin{tabular}{llll}
\hline & Value & S.E. & T - Stat. \\
\hline Beta & 5,207327 & 4,091517 & 1,272713 \\
Elasticity & $-0,28333$ & 0,553528 & $-0,51186$ \\
\hline
\end{tabular}

Simple Linear Regression - Analysis of Variance

\begin{tabular}{llcc}
\hline ANOVA & DF & Sum of Squares & Mean Square \\
\hline ANOVA & 1 & 6,887721 & 6,887721 \\
Regression & 5 & 131,4446 & 26,28892 \\
Residual & 6 & 138,3323 & \\
Total & 1,612239 & & \\
\hline \multicolumn{4}{l}{ Source: Calculation by Author }
\end{tabular}

The regression equation is equal to:

$Y=-0,4215 X+6,5262$

$R^{2}=0,1107$ 
According to the previous equation, if the parameter of non-performing loans increases by $1 \%$, the parameter return on average of shareholders' equity will be reduced by an average of about 0.41 percentage points. Also, the analysis of the relationship of parameters of non-performing assets and return on average shareholders' equity in the banking market in $\mathrm{BH}$ has shown that between these parameters there is a strong negative statistical relationship of nonlinear direction.

\section{Conclusion}

The most important task of a bank is to alleviate unforeseen losses in the bank and thus create confidence of the general public concerning legal capacity and efficiency of the bank. The possibility of banks to confront unforeseen business losses effectively depends primarily on the volume and structure of the bank capital and profitability. If we compare the importance of bank capital for the customers and for the bank itself, it can be concluded that the importance is much greater for the bank for a simple reason that capital is more exposed to risk. Also, we should keep in mind that there is a close connection between indicators of profitability and capital ratios. An adequate rate of bank capital in any case supports the rate of return, and vice versa. If the bank decides for the growth of the capital rate, it presents its financial strength, mobility, credibility and accenting with the growth rate of profitability to the public.

As the operations of the banking sector in the last four years have been under a strong influence of the economic crisis, i.e. adverse macroeconomic and financial developments both in the Eurozone and neighbouring countries, this situation is also reflected in the total real sector of the BH economy. The adequacy of the banking sector capital was held continuously above $16 \%$, whereby in the last two years it was $17 \%$ and $17.4 \%$. The main reason for this situation on the one hand is stagnation in credit growth and decline of total weighted risk. On the other hand, the banks retained the bulk of the profit in the previous year in the capital, and therefore the number of banks with additional capital injections improved the level of capitalization.

In this paper, we analysed the impact and interdependence of movement of non-performing assets with indicators of profitability for the period 2006 $\mathrm{Q} 1 / 2013$. The results of the analysis are indicators that there is a non-linear movement of the opposite sign between indicators of non-performing loans and the average return on assets, i.e. an increase in non-performing loans directly affected the decline in the return on average assets, as well as the decline in the return on average shareholders' equity. As already mentioned, the deterioration in asset quality resulted in the increase in non-performing loans in the portfolio. Thus, the problems related to the increase in non-performing loans, as well as the part that is not covered by loan loss reserves in the period ahead can significantly weaken the capital base in a number of banks if they continue the negative trends in the quality of assets and exacerbate the growth of non-performing loans. 


\section{References}

Alihodžić, A. (2012) Chesserov credit scoring model, Časopis: Banke u BiH, Sarajevo, broj: $136 .$, str. $44-45$.

Banking Agency of Federation of Bosnia and Herzegovina (2012) Information on banking system FBH, Available at:http://www.fba.ba/images/Publikacije_Banke/ INFORAMCIJA_BANKARSKI_SISTEM_31_12_2012_bos.pdf

Croxford, H.Abramson F. Jablonowski, A.,(2005) The Art of Better Retail Banking, John Wiley\&Sons LTD, Chichester UK.

Central Bank of Bosnia and Herzegovina (2012) Financial Stability Report, available at: http://www.cbbh.ba/files/financial_stability_report/fsr_2011_hr.pdf

Ćirović, M. (2001) Bankarstvo, Bridge Company, Beograd.

Directorate for Economic Planning (2012) Economic Trends, Annual Report, 2012, Available at: http://www.dep.gov.ba/dep_publikacije/ekonomski_trendovi/ Archive.aspx?langTag=bsBA\&template_id=140\&pageIndex=113.

Erić, D., Đukić, M. (2012) Finansijska tržišta u uslovima krize, Institut ekonomskih nauka, Beogradska bankarska akademija - Fakultet za bankarstvo, osiguranje i finansije, Beograd.

Greuning, H. V., Bratanović, S. B. (2009) Analyzing Banking Risk: A Framework for Assessing Corporate Governance and Risk Management, The International Bank for Reconstruction and Development/The World Bank, Washinggton.

Matić, V. (2011a) Bazel III - Uvođenje standarda opšte likvidnosti, Beograd: Bankarstvo, 3-4, str. 160. Available at: http://www.ubs-asb.com/Portals/0/Casopis/2011/3_4/ B03-04-2011-Ekoleks.pdf.

Matić, V. (2011b) Bazel II Izmenjeni koncept kapitala,Beograd, Časopis: Bankarstvo, broj: 7-8., str. 174-176. Dostupno na: http://www.ubsasb.com/Portals/0/Casopis/2011/7_8/UBS-Bankarstvo-07-08-2011-Ekoleks.pdf.

Mishkin, F. S. (2010) Ekonomija novca, bankarstva i financijskih tržišta, MATE doo Zagreb.

Milaković, N. (2004) Bazel II aktuelan i pored odlaganja - Projekat međunarodnog sporazuma o vlastitom kapitalu banke, Paragraf Press, broj 197. str. 45.

Newbold, P., Carlson, L.W., Thorne, B. (2010) Statistika za poslovanje i ekonomiju, MATE - Zagrebačka škola ekonomije i menadžmenta, šesto izdanje.

Vunjak, N., Kovačević, Lj. (2011) Bankarstvo: Bankarski menadžment, Ekonomski fakultet Subotica - Internacionalni Univerzitet Travnik - Proleter ad Bečej.

Vunjak, N., Ćurčić, U., Kovačević, Lj. (2008) Korporativno i investiciono bankarstvo, Proleter ad Bečej - Ekonomski fakultet Subotica - BLC Banja Luka Colege. 


\title{
ANALIZA KRETANJA NEKVALITETNIH KREDITA I PROFITABILNOSTI NA BANKOVNOM TRŽIŠTU U BIH
}

\begin{abstract}
Apstrakt: Glavni motiv poslovanja svake banke je ostvarenje što većeg profita kako bi se preko njega povećala dividenda akcionarima, te reinvestiranjem u akcije stvorili uslovi za povećanje sopstvenog finansijskog i kreditnog potencijala. Najvažniji indikator kvaliteta kreditnog portfolija je učešce nekvalitetnih kredita u ukupnim poslovnim sredstvima i plasmanima. U prvom kvartalu 2013. godine u $\mathrm{BiH}$ nastavljen je trend rasta nekvalitetnih kredita kod sektora pravnih lica u iznosu od 2,6\% dok je kod stanovništva došlo do stagnacije, tj. neznatnog smanjenja. Osnovni cilj ovog rada je da razmotri uticaj globalne finansijske krize te usporenog ekonomskog rasta na tendenciju kretanja nekvalitetnih kredita na bankovnom tržištu $u \mathrm{BiH}$, te međuzavisnost istih na kretanje pokazatelja profitabilnosti putem proste regresione jednačine.
\end{abstract}

Ključne reči: nekvalitetna aktiva, povrat na prosečni akcionarski kapital, povrat na prosečnu aktivu, regresiona analiza . 